\title{
Ethics
}

International Affairs

VOLUME $27 \cdot$ NUMBER $3 \cdot$ FALL 2013

\section{ROUNDTABLE: Nonproliferation} in the 21st Century

J. Bryan Hehir, Jacques E. C. Hymans, Nina Tannenwald, and Ward Wilson

\section{ES S A Y}

Hunger, Food Security, and the African Land Grab

Richard Schiffman

POLICY BRIEF

How We Count Hunger Matters

Frances Moore Lappé,

Jennifer Clapp, Molly Anderson, Robin Broad, Ellen Messer,

Thomas Pogge, and

Timothy Wise

\section{FEATURE}

The Nonproliferation

\section{Complex}

Campbell Craig and Jan Ruzicka

\section{R EVIEWS}

Just Business: Multinational Corporations and Human Rights

John Gerard Ruggie

REVIEW By RALPH STEINHARDT

The Human Right to Health Jonathan Wolff

Review by Joia S. MuKherJeE

Kant and the End of War: A Critique of Just War Theory Howard Williams

Kant and Cosmopolitanism: The Philosophical Ideal of World Citizenship Pauline Kleingeld

Review by Alyssa R. Bernstein 


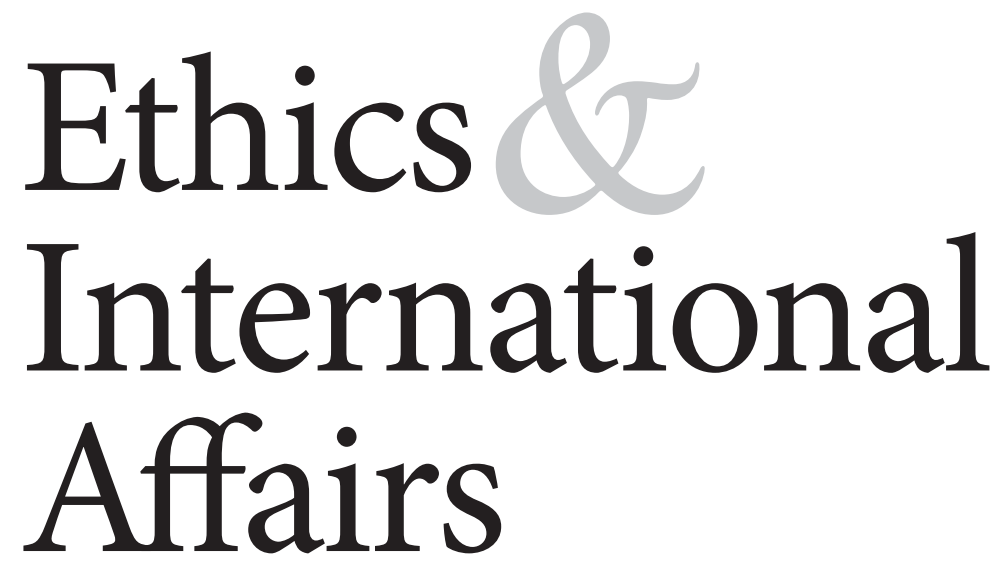

VOLUME $27 \cdot$ NUMBER $3 \cdot$ FALL 2013

\section{CARNEGIE}

The Voice for Ethics

in International Affairs 


\section{Ethics \& International Affairs}

\begin{tabular}{|c|c|c|c|}
\hline EDITOR IN CHIEF & Joel H. Rosenthal & EDITORIAL & Christian Barry \\
\hline EDITOR & John Tessitore & ADVISORY BOARD & Alex J. Bellamy \\
\hline $\begin{array}{l}\text { SENIOR EDITOR/ } \\
\text { MANAGING EDITOR }\end{array}$ & $\begin{array}{l}\text { Zornitsa Stoyanova- } \\
\text { Yerburgh }\end{array}$ & & $\begin{array}{l}\text { Allen Buchanan } \\
\text { Robyn Eckersley }\end{array}$ \\
\hline ASSOCIATE EDITOR & Zach Dorfman & & Joy Gordon \\
\hline EDITORIAL FELLOW & Chirag Barai & & Ian Hurd \\
\hline EDITORIAL INTERN & Emma Lecavalier & & Anthony F. Lang, Jr. \\
\hline COPY EDITOR & Meghan Lynn & & Anthony Langlois \\
\hline BUSINESS MANAGER & Eva Becker & & $\begin{array}{l}\text { David R. Mapel } \\
\text { Darrel Moellendorf } \\
\text { Terry Nardin } \\
\text { David Rodin } \\
\text { S. Prakash Sethi } \\
\text { Henry Shue } \\
\text { Jennifer Welsh } \\
\text { Leif Wenar }\end{array}$ \\
\hline
\end{tabular}

\section{Carnegie Council for Ethics in International Affairs}

The Carnegie Council for

Ethics in International Affairs is an independent, nonpartisan, nonsectarian, tax-exempt organization founded in 1914 by Andrew Carnegie. Since its beginnings, the Carnegie Council has asserted its strong belief that ethics, as informed by the world's principal moral and religious traditions, is an inevitable and integral component of all policy decisions, whether in the realm of economics, politics, or national security. The interrelationship of ethics and foreign policy is thus the unifying theme of all Carnegie Council programs. By promoting a greater understanding of the values and conditions that ensure peaceful relations among nations, the Carnegie Council hopes to contribute to a better life for people everywhere.

\section{BOARD OF TRUSTEES}

Joseph Amann

Kathleen Cheek-Milby

Phyllis D. Collins

Barbara Crossette

Thomas Donaldson

Richard A. Edlin

Anthony L. Faillace

Jonathan Gage, Vice Chairman
Stephen D. Hibbard, Treasurer

Haris Hromic

David P. Hunt

Bruce W. Jentleson

Zachary Karabell, Vice Chairman

Violy McCausland-Seve Amir Pasic
Alexander H. Platt

Joel H. Rosenthal, President

James H. Rowe

Robert G. Shaw,

Chairman

Michael J. Smith

James P. Wind

HONORARY TRUSTEES Charles M. Judd Maurice S. Spanbock, Esq. INTERNATIONAL HONORARY TRUSTEE Eiji Uehiro 


\title{
Contents
}

\author{
Contributors 237
}

ESSAY Hunger, Food Security, and the African Land Grab

Richard Schiffman 239

POLICY BRIEF How We Count Hunger Matters

Frances Moore Lappé, Jennifer Clapp, Molly Anderson, Robin Broad, Ellen Messer, Thomas Pogge, and Timothy Wise 251

ROUNDTABLE: Nonproliferation: A Global Issue for a Global Ethic

NONPROLIFERATION J. Bryan Hehir 261

IN THE $21^{\text {ST }}$

CENTURY

The Threat of Nuclear Proliferation: Perception and Reality Jacques E. C. Hymans 281

Justice and Fairness in the Nuclear Nonproliferation Regime Nina Tannenwald 299

The Gordian Knot: Moral Debate and Nuclear Weapons

Ward Wilson 319

FEATURE The Nonproliferation Complex

Campbell Craig and Jan Ruzicka 329

REVIEWS Just Business: Multinational Corporations and Human Rights John Gerard Ruggie

Review by Ralph Steinhardt 349

The Human Right to Health

Jonathan Wolff

Review by Joia S. Mukherjee 351

Kant and the End of War: A Critique of Just War Theory

Howard Williams

Kant and Cosmopolitanism: The Philosophical Ideal of World

Citizenship

Pauline Kleingeld

Review by Alyssa R. Bernstein 354

SUBMISSIONS Guidelines for Submission

RESOURCES For additional Carnegie Council resources on the topics addressed in these pages, please visit www.eiajournal.org. 
ETHICS \& INTERNATIONAL AFFAIRS (ISSN 0892-6794 print; ISSN 1747-7093 online).

\section{Publisher}

Ethics \& International Affairs is published quarterly by Cambridge University Press, 32 Avenue of the Americas, New York, NY 10013.

\section{Information for subscribers}

Ethics \& International Affairs is published in four issues per year. Institutional subscription prices for 2013 are: Print \& Online: US \$429 in the USA, Canada, and Mexico; UK $£_{263}+$ VAT elsewhere. Institutions electronic only: US\$390 in the USA, Canada, and Mexico; UK£237 + VAT elsewhere. Individuals print only: US\$41 in the USA, Canada, and Mexico; UK£28 + VAT elsewhere. Correspondence concerning subscriptions should be sent to: Cambridge University Press, 100 Brook Hill Drive, West Nyack, NY 10994, USA for customers in the USA, Canada, or Mexico. Customers elsewhere should contact: Cambridge University Press, The Edinburgh Building, Shaftesbury Road, Cambridge CB2 8RU, UK. The price includes online access to the current and all online back files to January 1st 1997, where available.

\section{Delivery Terms and Legal Title}

Prices include delivery of print journals to the recipient's address. Delivery terms are Delivered Duty Unpaid (DDU); the recipient is responsible for paying any import duty or taxes. Legal title passes to the customer on despatch by our distributors.

Production Editor: Diane Davis (email: ddavis@cambridge.org).

Electronic Access Access to this journal is available free online within institutions in the developing world through the AGORA initiative with the FAO, the HINARI initiative with the WHO and the OARE initiative with UNEP. For information, visit www.aginternetwork.org, www.healthinternetwork.org, www.oarescience.org. Abstracting and Indexing Services The Journal is indexed by Academic Search (EBSCO), Academic Search Premier (EBSCO), CSA Environmental Sciences \& Pollution Management Database (CSA/CIG), CSA Sustainability Science Abstracts (CSA/CIG), Current Abstracts (EBSCO), Current Contents ${ }^{\circledast} /$ Social and Behavioral Sciences (Thomson Reuters), Expanded Academic ASAP (Thomson Gale), IBSS: International Bibliography of the Social Sciences (LSE), InfoTrac, International Political Science Abstracts (IPSA), Journal Citation Reports/ Social Sciences Edition (Thomson Reuters), OMNIFILE Full Text Mega Edition (OMNIFILE), PAIS: Public Affairs Information Service (CSA/CIG), Proquest 5000 (ProQuest), Proquest Discovery (ProQuest), Proquest Platinum (ProQuest), Proquest Research Library (ProQuest), Proquest Social Science Journals (ProQuest), Social Sciences Citation Index (Thomson Reuters), Social Sciences Index/Abstracts (HW Wilson), Student Resource Center College (w/ Academic ASAP),Wilson OMNIFILE Full Text Select (HW Wilson) and Worldwide Political Sciences Abstracts (CSA/CIG).

Disclaimer The Publisher, Carnegie Council, and Editors cannot be held responsible for errors or any consequences arising from the use of information contained in this journal; the views and opinions expressed do not necessarily reflect those of the Publisher, Council and Editors, neither does the publication of advertisements constitute any endorsement by the Publisher, Council and Editors of the products advertised.

Copyright and Photocopying Copyright (C) 2013 Carnegie Council for Ethics in International Affairs. All rights reserved. No part of this publication may be reproduced, in any form or by any means, electronic, photocopying, or otherwise, without permission in writing from Cambridge University Press. Policies, request forms, and contacts are available at: http://www.cambridge.org/rights/permissions/permission.htm Permission to copy (for users in the U.S.A.) is available from Copyright Clearance Center, http://www.copyright.com, email: info@copyright.com.

Printed in USA by The Sheridan Press.

View this journal online at journals.cambridge.org/EIA.

ISSN 0892-6794 (Print)

ISSN 1747-7093 (Online) 


\section{Ethics \& International Affairs}

